\title{
Immunology, toxicology
}

\section{IMMUNE STATUS OF ALBINO RATS UNDER EXPERIMENTAL INFECTION CAUSED BY Salmonella cholera suis AT SUBACUTE T-2 TOXICOSIS}

\section{A.G. SHAKHOV, L.Yu. SASHNINA, Yu.N. MAS'YANOV, G.A. VOSTROILOVA, I.Yu. TAFINTSEVA}

All-Russian Research Veterinary Institute of Pathology, Pharmacology and Therapy, Russian Academy of Agricultural Sciences, 114-b, ul. Lomonosova, Voronezh, 394087 Russia, e-mail A.G.Shakhov@mail.ru, L.Yu.Sashnina@mail.ru, nivipat@mail.ru, irentaf@mail.ru

Received February 24, 2015

\section{Abstract}

Modern animal husbandry is faced with ecological problems, caused by micotoxine feed contamination, presence of potentially pathogenic microorganisms (Escherichia, Salmonella, coccal microflora, etc.) and various xenobiotics of physical and chemical nature in the animal environment. Total impact of commercial farm immunopathogenic factors on the animals is of particular concern. Therefore, combination of T-2 toxin and Salmonella cholerae suis impact on the albino rats' immune status was experimentally studied. The researches made stated that salmonella contamination against the background of subacute T-2 toxin was accompanied by significant changes of gemomorphological and immune statuses. Evident neutrophilia onset in animals was accompanied by IL-1 $\beta$ concentration increase. Insignificant increase of humoral (serum bactericidal activity, SBA) nonspecific immunity was determined by synergistic effect of toxin and infectious agent. Complementary blood serum activity, which was necessary for the increase of organism's resistance to intoxication, increased in proportion to the toxin and salmonella doses increase. Contamination of albino rats by both doses of infectious agent against the background of T-2 toxicosis was accompanied by the increase in preantibodies titer, significant decrease in phagocytic activity of leukocytes (PAL), phagocytic number (PN), phagocytic index (PI), and also in lysozyme content, which were the first line of organism protection, and evident suppression of T-lymphocytes, especially in animals, induced by a higher dose of salmonella. The decrease of T-cells number was accompanied by a lower IL-2 blood concentration. T-2 fed to rats against the background of salmonella intoxication promoted enhancement of humoral immunity stimulation. It was accompanied by the increase of B-lymphocytes (percent) differentiation, blood concentration of common immunoglobulins and induction of antisalmonella antibodies and was also accompanied by $\mathrm{C}$-reactive protein appearance in blood, which revealed inflammatory process development. The obtained experimental data prove an imbalance between functioning of the animals' protective systems under ecological problems simulated by toxicant and potential pathogen, which are characterized by suppression of protein synthesis, T-link of the immune system, decrease of IL-2 level, phagocytosis, increase of immunoglobulins catabolism, lysozyme and per contra by the increase of complement system proteins content, IL-1 $\beta$, activation of humoral immunity, IL-4 production, leukocytosis, neutrophilia and acute-phase protein biosynthesis (APPB).

Keywords: albino rats, T-2 toxin, salmonella, cytokines, T- and B-lymphocytes, antibodies, phagocytosis, whole protein, protein fractions, blood cells, natural resistance, C-reactive protein.

Modern animal husbandry faces a disturbed ecological system when various man-made (physical, chemical and biological) factors adversely affect the body resulting in the development of pathological conditions [1-5].

The mycotoxin background considerably contributes to ecological problems. Mycotoxins represent a group of structurally different secondary metabolites of fungi exerting a marked toxic effect on the body of animals and people via the food. In addition to the direct toxic effect, mycotoxins increase susceptibility of farm animals to infectious diseases [6-11].

One of the most commonly encountered fungal xenobiotics is T-2 toxin. This is a type A trichothecene mycotoxin produced by representatives of the genus Fusarium. The main effects of T-2 toxin include marked immunosuppres- 
sion, which makes the body more vulnerable to various pathogens [12-14].

The immune system of animals kept at large farms in ecologically unfavorable zones is exposed to a double load, viz. a direct effect of polluting factors and a growing persistent potential of microorganisms disturbing pre-immune and immune mechanisms protecting from infections. Under these conditions, nonspecific resistance and immunity of the body are more likely to decrease, secondary immunopathological conditions and subsequent infectious complications and diseases might occur [15-18]. The latter should include gastrointestinal and respiratory infections of young farm animals, one of the causative agents of which is Salmonella possessing immunosuppressive properties [19, 20]. A number of researchers indicate that the carrier state of pathologic Salmonella is not uncommon among animals and people [21, 22].

The purpose of this work was to study the effects of Salmonella cholerae suis infection against the background of subacute $\mathrm{T}-2$ toxicosis on the immune status of albino rats in the experiment simulating ecologically unfavorable conditions close to those found in the commercial swine production.

Technique. The experiments were carried out under vivarium conditions on mature albino outbred rats with the body weight of 230-250 g. The animals were kept in standard plastic cages (8-10 animals in each) on the bedding of hardwood shavings in accordance with the guidelines for accommodation and care of confined groups of animals. The air temperature was maintained within the range of $18-23{ }^{\circ} \mathrm{C}$, with relative humidity of $45 \%-60 \%$. These values were registered on a daily basis. Access to water and feedstuff was unlimited. The researches selected healthy animals for the experiment. The groups were formed on the principle of analogy using body weight as a criterion (the differences in the average weight of animals did not exceed 10-12\%). The housing conditions, feeding and performed procedures complied with the provisions of the European Convention for the Protection of Vertebrate Animals Used for Experimental and Other Scientific Purposes (Strasbourg, 1986), and Good Laboratory Practice in the Russian Federation (GOST R 53434-2009) [23].

Five groups of albino rats were formed $(n=12)$. Group I (control) included intact animals. The other rats received T-2 toxin with their feedstuff in the doses of $0.05 \mathrm{LD}_{50}(140 \mu \mathrm{g} / \mathrm{kg}$, groups II and III $)$ and $0.20 \mathrm{LD}_{50}(560 \mu \mathrm{g} / \mathrm{kg}$, groups IV and V) (subacute intoxication) for 6 days. And 1 day later, the animals were intraabdominally infected with 1-day culture of Salmonella cholerae suis in the doses of $1.00 \mathrm{LD}_{50}(1.90 \mathrm{bln}$ of cells, groups II and IV) and $1.25 \mathrm{LD}_{50}(1.95$ bln of cells, groups III and V). The rats were clinically observed for 6 days after the introduction of infection, with incidence rate, symptom complex and mortality taken into account. On day 7 , the researchers determined morphological indices of blood and the immune status of the infected and intact animals.

An ABX Micros 60 analyzer (Horiba, France) was used for the morphological analysis of blood. Bactericidal (BSBA), complementary (BSCA) and lysozyme (BSLA) activities of blood serum, phagocytic activity of leukocytes (PAL), phagocyte count (PC), phagocytic index (PI) and natural antibodies (NAB) were determined in accordance with the Guidelines for Assessment and Correction of Non-specific Resistance of Animals [24]; anti-salmonella antibodies were identified by the agglutination reaction (AR); absolute and relative counts of T-lymphocytes were estimated by the spontaneous rosette formation test (E-RF) with guinea pig erythrocytes; B-lymphocytes were evaluated by complement-dependent rosette formation (EAC-RF) in accordance with the Guidelines for Assessment and Correction of Immune Status of Animals [25]; total immunoglobulin level was assayed using the zinc sulfate precipitation test [26]; C-reactive protein (CRP) was 
estimated by the latex method. Concentrations of IL-1 $\beta$, IL-2 and IL-4 cytokines in the blood serum were quantified by the enzyme-linked immunosorbent assay according to the approved techniques accompanying the Vektor-Best diagnostic kits (Russia).

The bacteriological investigations into the specificity of death of animals were performed by standard methods according to instructions [27].

Statistical processing of the obtained data was carried out using Statistica v. 6.1 software; the confidence was assessed by the Student's $t$-test [28].

Results. The clinical signs of Salmonella infection against the background of subacute intoxication in rats were manifested in the form of suppression of locomotor activity, decreased appetite, ruffled fur, weaker responses to external stimuli, hyperemic visible mucous membranes, unformed faeces, with intractable diarrhea noted in the majority of animals.

It was found that 6 days after the introduction of the infection in the dose of $140 \mu \mathrm{g} / \mathrm{kg}$ against the background of T-2 toxicosis, the body weight of albino rats in groups II and III decreased as compared with the control group by $13.8 \%$ and $17.5 \%$ correspondingly. The clinical manifestation of the infection was registered in $75.0 \%$ and $83.3 \%$ of rats; and $3(25.0 \%)$ and $4(33.3 \%)$ animals died.

With subacute T-2 intoxication in the dose of $560 \mu \mathrm{g} / \mathrm{kg}$ and the infection of the albino rats with salmonella in the doses of 1.9 bln cells (group IV) and 1.95 bln cells (group V), 6 days later the dose-related reduction in the body weight was more considerable as compared with the control, i.e. by 20.0 $\%$ and $24.9 \%$, correspondingly. The clinical signs of infection were identified in $91.6 \%$ and $100 \%$ of rats. Over the specified period, $5(41.7 \%)$ and 6 $(50.0 \%)$ animals died.

1. Hematological indices of blood in outbred albino rats infected with Salmonella cholerae suis against the background of $\mathrm{T}-2$ toxicosis $(M \pm m$, laboratory experiment)

\begin{tabular}{|c|c|c|c|c|c|}
\hline \multirow{2}{*}{ Index } & \multicolumn{5}{|c|}{ Group } \\
\hline & I (control) & II & III & IV & $\mathrm{V}$ \\
\hline Erythrocytes, $\times 10^{12} / 1$ & $6.8 \pm 0.05$ & $5.4 \pm 0.11^{* * *}$ & $5.2 \pm 0.16^{* * *}$ & $5.5 \pm 0.08^{* * *}$ & $5.4 \pm 0.17^{* * *}$ \\
\hline Hemoglobin, g/1 & $153.9 \pm 1.40$ & $106.8 \pm 2.00^{* * *}$ & $108.5 \pm 4.20^{* * *}$ & $107.3 \pm 1.80^{* * *}$ & $107.2 \pm 3.10^{* * *}$ \\
\hline Hematocrit, $\%$ & $46.8 \pm 0.39$ & $35.0 \pm 0.57^{* * *}$ & $33.5 \pm 0.99^{* * *}$ & $33.8 \pm 0.73^{* * *}$ & $34.0 \pm 1.04^{* * *}$ \\
\hline Leukocytes, $\times 10^{9} / 1$ & $6.5 \pm 0.21$ & $7.6 \pm 0.16^{* * *}$ & $7.6 \pm 0.71^{* *}$ & $8.4 \pm 0.72^{* *}$ & $11.8 \pm 1.82^{* *}$ \\
\hline Neutrophils: & & & & & \\
\hline banded, $\%$ & $1.1 \pm 0.07$ & $1.7 \pm 0.32^{*}$ & $1.8 \pm 0.21^{* *}$ & $1.5 \pm 0.20^{*}$ & $1.4 \pm 0.25^{* * *}$ \\
\hline segmented,\% & $37.1 \pm 2.93$ & $63.9 \pm 4.22^{* * *}$ & $72.0 \pm 1.62^{* * *}$ & $63.7 \pm 3.62^{* * *}$ & $70.6 \pm 3.12^{\text {*** }}$ \\
\hline Eosinophiles, $\%$ & $3.7 \pm 0.51$ & $0.2 \pm 0.16^{* * *}$ & $0.4 \pm 0.21^{* * *}$ & $0.6 \pm 0.33^{* * *}$ & - \\
\hline Monocytes, $\%$ & $2.8 \pm 0.33$ & $2.4 \pm 0.26$ & $2.2 \pm 0.70$ & $2.0 \pm 0.06^{* *}$ & $1.9 \pm 0.05^{* *}$ \\
\hline Lymphocytes, $\%$ & $55.6 \pm 2.57$ & $31.8 \pm 1.83^{* * *}$ & $22.6 \pm 1.65^{* * *}$ & $30.8 \pm 2.40^{* * *}$ & $25.8 \pm 2.51^{* * *}$ \\
\hline
\end{tabular}

As compared with the intact animals, the rats from experimental groups II, III, IV and V (Table 1) demonstrated considerable but approximately equal reduction in the erythrocytes count (by $20.6 \%, 23.5 \%, 19.1 \%$, and $20.6 \%$, correspondingly), in hemoglobin (by $30.6 \%, 29.5 \%, 30.3 \%$, and $30.0 \%$, correspondingly), and in hematocrit (by $21.6 \%, 25.2 \%, 27.8 \%$, and $27.4 \%$, correspondingly), indicating a synergistic effect of T-2 toxin and Salmonella exo- and endotoxins on erythrocytes, suppression of erythropoiesis, development of anemia and abnormal tissue oxygenation [29].

Moreover, the leukocyte counts in the blood of the animals increased by $16.9 \%, 16.9 \%, 29.2 \%$, and $81.5 \%$ due to the increase in the segmented (by $72.2 \%, 94.0 \%, 71.7 \%$, and $90.3 \%$ ) and banded (by $54.5 \%, 63.6 \%, 36.3 \%$ and $27.3 \%$ ) neutrophil counts, which indicates a dose-related intensification of 
neutrophilic leukocyte generation in the bone marrow and their migration into the blood circulation system and further into mucous membrane tissues in the animals subjected to intoxication and to antigenic action.

Marked neutrophilia in the rats from experimental groups II, III, IV, V was combined with 2.3-, 2.4-, 2.3- and 2.37-time increase in the concentration of IL-1 $\beta$, stimulating the release of neutrophils from the bone marrow, as compared with the indicators of the control animals (Table 2).

2. Indicators of immune status in outbred albino rats infected with Salmonella cholerae suis against the background of T-2 toxicosis ( $M \pm m$, laboratory experiment)

\begin{tabular}{|c|c|c|c|c|c|}
\hline \multirow{2}{*}{ Index } & \multicolumn{5}{|c|}{ Group } \\
\hline & I (control) & II & III & IV & $\mathrm{V}$ \\
\hline BSBA, $\%$ & $53.5 \pm 2.83$ & $58.3 \pm 2.62$ & $57.9 \pm 3.75$ & $51.7 \pm 1.58$ & $53.5 \pm 6.65$ \\
\hline BSCA, \% & $6.23 \pm 0.57$ & $16.6 \pm 2.52^{* * *}$ & $20.8 \pm 2.33^{* * *}$ & $23.1 \pm 4.07^{* * *}$ & $23.7 \pm 4.02 * * *$ \\
\hline BSLA, mg/1 & $1.80 \pm 0.23$ & $1.48 \pm 0.13$ & $1.49 \pm 0.10$ & $1.45 \pm 0.10$ & $1.56 \pm 0.05$ \\
\hline \multicolumn{6}{|l|}{ Lymphocytes: } \\
\hline percentage, $\%$ & $55.6 \pm 2.60$ & $31.8 \pm 1.80^{* * *}$ & $22.6 \pm 1.70^{* * *}$ & $30.8 \pm 2.40^{* * *}$ & $25.8 \pm 2.50^{* * *}$ \\
\hline total, $\times 10^{9} / 1$ & $3.65 \pm 0.21$ & $2.37 \pm 0.22^{* *}$ & $1.72 \pm 0.25^{* * *}$ & $2.55 \pm 0.34^{* *}$ & $2.76 \pm 0.50^{*}$ \\
\hline \multicolumn{6}{|l|}{ T-lymphocytes: } \\
\hline percentage, $\%$ & $34.7 \pm 0.23$ & $27.6 \pm 3.94^{*}$ & $23.6 \pm 1.18^{*}$ & $17.4 \pm 1.28^{* * *}$ & $16.5 \pm 1.90^{* * *}$ \\
\hline total, $\times 10^{9} / 1$ & $1.21 \pm 0.17$ & $0.71 \pm 0.10^{*}$ & $0.37 \pm 0.07^{* * *}$ & $0.43 \pm 0.04^{* * *}$ & $0.44 \pm 0.08^{* * *}$ \\
\hline \multicolumn{6}{|l|}{ B-lymphocytes: } \\
\hline percentage, $\%$ & $9.3 \pm 0.83$ & $10.4 \pm 1.23$ & $13.0 \pm 1.03^{* *}$ & $13.3 \pm 2.70^{* * *}$ & $14.2 \pm 1.37^{* * *}$ \\
\hline total, $\times 10^{9} / 1$ & $0.41 \pm 0.06$ & $0.27 \pm 0.03^{* *}$ & $0.20 \pm 0.02$ & $0.33 \pm 0.07$ & $0.39 \pm 0.07$ \\
\hline PAL, $\%$ & $72.3 \pm 1.16$ & $60.0 \pm 1.37^{* * *}$ & $60.7 \pm 2.77^{* * *}$ & $50.3 \pm 2.85^{* * *}$ & $46.4 \pm 1.47^{* * *}$ \\
\hline $\mathrm{PC}$ & $5.0 \pm 0.14$ & $3.3 \pm 0.23^{* * *}$ & $3.5 \pm 0.34^{* * *}$ & $2.4 \pm 0.10^{* * *}$ & $2.4 \pm 0.15^{* * *}$ \\
\hline PI & $7.0 \pm 0.17$ & $5.5 \pm 0.35^{* * *}$ & $5.8 \pm 0.31^{* *}$ & $4.7 \pm 0.23^{* * *}$ & $5.2 \pm 0.23^{* * *}$ \\
\hline Immunoglobulins, g/1 & $20.7 \pm 0.93$ & $15.6 \pm 0.75^{* * *}$ & $16.4 \pm 1.01^{* * *}$ & $16.7 \pm 0.99^{* *}$ & $19.4 \pm 0.51$ \\
\hline \multirow[t]{2}{*}{ Normal antibodies } & $1: 6.5 \pm 0.73$ & $1: 12.7 \pm 1.20^{* * *}$ & $1: 13$ & $1: 13$ & $1: 14$ \\
\hline & & & AM. $1 \pm 0.20^{* * *}$ & AM. $3 \pm 1.40^{* * *}$ & AM. $0 \pm 1.20^{* * *}$ \\
\hline Antibody titers & - & $1: 167 \pm 21.1$ & $1: 171 \pm 18.4$ & $1: 140 \pm 24.5$ & $1: 160 \pm 24.5$ \\
\hline C-reactive protein & - & $1: 3.0 \pm 0.50^{* * *}$ & $1: 2.6 \pm 0.30^{* * *}$ & $1: 4.7 \pm 2.30^{*}$ & $1: 5.2 \pm 1.20^{* * *}$ \\
\hline $\mathrm{IL}-1 \beta, \mathrm{pg} / \mathrm{ml}$ & $60.8 \pm 8.30$ & $140.0 \pm 9.60^{* * *}$ & $148.1 \pm 74.60$ & $139.6 \pm 20.30^{* *}$ & $143.8 \pm 20.80^{* *}$ \\
\hline $\mathrm{IL}-2, \mathrm{pg} / \mathrm{ml}$ & $249.7 \pm 31.10$ & $185.6 \pm 8.40$ & $188.9 \pm 14.80$ & $223.9 \pm 12.10$ & $195.1 \pm 8.70$ \\
\hline $\mathrm{IL}-4, \mathrm{pg} / \mathrm{ml}$ & $46.3 \pm 1.40$ & $48.1 \pm 5.80$ & $48.7 \pm 5.30$ & $46.7 \pm 3.90$ & $51.4 \pm 3.70$ \\
\hline \multicolumn{6}{|c|}{$\begin{array}{l}\text { N o t e s: Group descriptions see in «Technique» section. BSBA }- \text { blood serum bactericidal activity, BSCA - } \\
\text { blood serum complementary activity, BSLA - blood serum lysozyme activity, PAL }- \text { phagocytic activity of leu- } \\
\text { kocytes, PC }- \text { phagocyte count, PI }- \text { phagocytic index, IL }- \text { interleukin; «-» }- \text { negative result of the determi- } \\
\text { nation. } \\
{ }^{*},{ }^{* *},{ }^{* * *} \mathrm{p} \leq 0.05 ; \mathrm{p} \leq 0.01 ; \mathrm{p} \leq 0.001 \text {, correspondingly. }\end{array}$} \\
\hline
\end{tabular}

On the other hand, the percentage of lymphocytes decreased considerably (by $42.8 \%, 59.4 \%, 44.6 \%$, and $53.6 \%$, correspondingly); the same was true for the eosinophil counts (a decrease by $94.6 \%, 89.2 \%$ and $83.7 \%$ in the rats from groups II, III and IV), which was not detected in the animals from group $\mathrm{V}$.

The reduction in the relative count of monocytes, predecessors of tissueresident macrophages that fulfill phagocytic, antigen-presenting and reparative functions, was dose-related and amounted in the groups to $14.3 \% 21.4 \%$ $28.6 \%$, and $32.1 \%$ compared to the control, which indicated the weakening of cellular protection and blood formation function. T-2 toxin has been shown to have a cytotoxic effect on monocytes as well as to inhibit their differentiation into dendritic cells or macrophages [30].

Against the background of $\mathrm{T}-2$ toxicosis $(140 \mu \mathrm{g} / \mathrm{kg})$, the rats from groups II and III developed marked T-deficit, especially in the group with a higher dose of Salmonella, which was evidenced by the reduction in the relative count of T-cells by $20.5 \%$ and $32.0 \%$, and in the absolute count by $41.3 \%$ and $69.4 \%$, correspondingly, as compared with those in the intact animals.

Infection of the animals against the background of the subacute intoxication with a high dose of the toxin $(560 \mu \mathrm{g} / \mathrm{kg})$ was accompanied by the most pronounced suppression of the T-lymphocyte system, especially when the dose 
of Salmonella was 1.95 bln cells: in groups IV and V, the relative count of Tcells decreased by $49.9 \%$ and $52.4 \%$, the absolute numner decreased by $64.5 \%$ and $63.6 \%$ as compared with the control.

In all the experimental rats, the reduction in the T-cell count was combined with lower (by $10.3 \%, 21.9 \%, 25.7 \%$, and $24.3 \%$ ) concentrations of IL2, a growth factor of T-lymphocytes, which stimulates the immune response by activation of $\mathrm{T}$-cell populations. It was determined that $\mathrm{T}$ - and $\mathrm{B}$-lymphocytes were the most sensitive cells among others to the action of T-2 toxin [31].

Marked humoral immunodeficiency was registered in the rats from experimental groups II, III, IV and V. The concentration of total immunoglobulins in their blood was lower than in the intact animals by $24.6 \%, 20.8 \%, 19.3 \%$, and $6.3 \%$, correspondingly, which was combined with the reduction in the absolute count of B-lymphocytes by $34.1 \%, 51.2 \%, 19.5 \%$ and $4.9 \%$.

As we can see, the reduction in the immunoglobulin percentage depended inversely on the increase in the toxicant and Salmonella doses, which may indicate a dose-related activation of the humoral immunity in the rats against the background of more intense catabolism.

This more pronounced stimulation of the humoral immunity in the animals from groups IV and $\mathrm{V}$ was confirmed by the increase in the relative count of B-cells by $43.0 \%$ and $52.7 \%$, correspondingly, as compared with the control. In the animals from groups II and III, this indicator increased by $11.8 \%$ and $39.8 \%$.

The antibody titers against Salmonella depended directly on the amount of the administered Salmonella, but were somewhat lower in the rats intoxicated with $560 \mu \mathrm{g} / \mathrm{kg}$ of toxin, which might be explained by the considerable suppression of the T-group of the immune system.

Besides, we can assume a marked polyclonal stimulation of the humoral immunity in the rats from group IV and especially from group V, which appeared as a result of an increased antigenic action, was accompanied by an increase in the total amount of immunoglobulins, and competed with a clonespecific response focused on the synthesis of specific antibodies.

In general, the animals from the experimental groups demonstrated positive correlation between the total immunoglobulin levels, relative count of Blymphocytes and IL-4, a B-cell growth factor stimulating immunoglobulin generation and produced mainly by the population of T-helper lymphocytes of the $2^{\text {nd }}$ class, which are responsible for the development of the humoral immunity.

Infection of the rats from groups II and III with Salmonella against the background of $\mathrm{T}-2$ toxicosis $(140 \mu \mathrm{g} / \mathrm{kg})$ was accompanied by an increase in BSBA by $9.0 \%$ and $8.2 \%$, but a higher dose of the toxin $(560 \mathrm{mcg} / \mathrm{kg})$ received by the animals from groups IV and V did not change this indicator much as compared with the control.

In groups II, III, IV and V, the blood serum complementary activity necessary for the body to enhance its resistance to intoxication, on the contrary, increased proportionally to the increase in the doses of the toxin and Salmonella and was $2.7,3.3,3.7$, and 3.8 times higher, correspondingly. The intoxication can be assumed to have stimulated the synthesis and activation of proteins of the complement system.

The lysozyme content in the blood serum was below the control indicator by $17.8 \%$ and $17.2 \%$ in the rats from groups II and III and by $19.4 \%$ and $13.3 \%$ in the animals from groups IV and V, which is related to the reduction in PAL and the absorbing capacity of phagocytes under the action of various toxins.

The infection of the albino rats in all the experimental groups with Sal- 
monella against the background of $\mathrm{T}-2$ toxicosis was accompanied by a reduction in the total protein in blood serum by $11.8 \%, 9.4 \%, 13.9 \%$, and $11.6 \%$, with albumin levels reduced by $21.7 \%, 24.5 \%, 19.0$, and $20.9 \%$, and an increase in the $\alpha$-globulin content by $80.2 \%, 47.7 \%, 67.4 \%$, and $88.4 \%$, and in $\beta$-globulin content by $30.5 \%, 26.9 \%, 24.7 \%$, and $22.4 \%$. The concentration of $\gamma$-globulins in the albino rats from groups II, IV and V decreased by $22.8 \%$, $18.4 \%$, and $19.6 \%$, correspondingly, with a slight increase in the animals from group III (Table 3).

3. Content of total protein and its fractions in the outbred albino rats infected by Salmonella cholerae suis against the background of T-2 toxicosis ( $M \pm m$, laboratory experiment)

\begin{tabular}{|c|c|c|c|c|c|}
\hline \multirow{2}{*}{ Index } & \multicolumn{5}{|c|}{ Group } \\
\hline & I (control) & II & III & IV & $\mathrm{V}$ \\
\hline Protein g/l & $70.5 \pm 1.25$ & $62.2 \pm 0.95^{* * *}$ & $63.9 \pm 0.77^{* * *}$ & $60.7 \pm 1.17^{* * *}$ & $62.3 \pm 0.77^{* * *}$ \\
\hline Albumins, $\%$ & $55.4 \pm 1.68$ & $43.4 \pm 0.61^{* * *}$ & $41.8 \pm 1.62^{* * *}$ & $44.9 \pm 1.16^{* * *}$ & $43.8 \pm 0.71^{* * *}$ \\
\hline$\alpha$-Globulins, $\%$ & $8.6 \pm 0.58$ & $15.5 \pm 0.21^{* * *}$ & $12.7 \pm 1.26^{* *}$ & $14.4 \pm 1.13^{* * *}$ & $16.2 \pm 0.32^{* * *}$ \\
\hline$\beta$-Globulins, $\%$ & $22.3 \pm 0.89$ & $29.1 \pm 0.32^{* * *}$ & $28.3 \pm 0.70^{* * *}$ & $27.8 \pm 0.61^{* * *}$ & $27.3 \pm 0.57^{* * *}$ \\
\hline$\gamma$-Globulins, $\%$ & $15.8 \pm 0.84$ & $12.2 \pm 0.56^{* *}$ & $17.2 \pm 0.93$ & $12.9 \pm 0.24^{* *}$ & $12.7 \pm 0.30^{* *}$ \\
\hline $\mathrm{A} / \mathrm{G}$ & 1.19 & 0.76 & 0.72 & 0.81 & 0.78 \\
\hline
\end{tabular}

The noted reduction in the total protein count in blood serum of the animals from all the experimental groups as compared with the control is related to the weakening of the liver's synthetic capability. The reduction in the content of albumins was caused by the need to use them as the most important factor of plasma detoxification, fixation and removal of toxins.

$\alpha$-Globulins include acute phase proteins, $\beta$-globulins include the majority of proteins of the complement system and a part of immunoglobulins. The considerable increase in the content of $\alpha$ - and $\beta$-globulins noted in the albino rats was due to the development of an inflammatory process.

Almost all diseases, especially inflammatory ones, are accompanied by an increase in the content of $\gamma$-globulins in blood serum. In our experiments, we registered a reduction in the $\gamma$-globulin concentrations apparently attributable to the fact that they were used to neutralize and weaken the combined pathogenic action of Salmonella and T-2 toxin.

The considerable reduction in the albumin-globulin ratio $(\mathrm{A} / \mathrm{G})$ was noted in the animals from the experimental groups (by $36.1 \%, 39.5 \%$, $31.9 \%$, and $34.5 \%$, correspondingly) compared to control $\mathrm{A} / \mathrm{G}=1.19$, indicative of an inhibitory action of T-2 toxin and Salmonella on the protein biosythensis (see Table 3) (32).

In groups II, III, IV and V, we noted a considerable reduction in PAL (by $17.0 \%, 16.1 \%, 30.4 \%$, and $35.8 \%$ ); in PC (by $34.0 \%, 30.0 \%$, $52.0 \%$ and $52.0 \%$ ); and in PI (by $21.4 \%, 17.1 \%, 32.9 \%$ and $25.7 \%$, correspondingly).

The absolute amount of lysozyme produced by phagocytes was consistent with the indicators of the neutrophil phagocytic capacity (the product of the absolute count of segmented neutrophils and PC), which equaled in 16.0, 19.1, 12.8 , and 20.0 thou. cells $/ \mathrm{mm}^{3}$, correspondingly, for the rats from the experimental groups (12.1 thou. cells $/ \mathrm{mm}^{3}$ for the intact animals). Moreover, against the background of a lower content of lysozyme in blood, these higher values of the neutrophil phagocytic capacity in the animals subjected to the intoxication and infection may indicate an increased consumption of the enzyme as a result of the intensification of the antigenic action.

The considerable increase in the content of leukocytes, neutrophils, IL- 
$1 \beta$, total hemolytic activity of the complement, activation of the humoral immunity, higher titers of natural and specific antibodies in the rats from the experimental groups could imply the development of an inflammatory process [33]. It was confirmed by a positive C-reactive protein response, which serves as a marker of the acute phase of inflammation and was detected in the titers of 1:3.0, 1:2.6, 1:4.7, and 1:5.2, correspondingly, in the rats from the experimental groups. Moreover, it was established that it was only the infection of rats against the background of the intoxication which initiated the synthesis of C-reactive protein, which was not observed in cases of separate T-2 toxin administration [34] or infection with Salmonella [35].

The experimental data evidence that the infection of albino rats with Salmonella against the background of subacute intoxication with T-2 toxin was accompanied by changes in the hemomorphological and immune statuses. Appeared marked neutrophilia was combined with a significant (2.3-2.4 times) increase in IL-1 $\beta$ concentration in blood. A minor increase in the humoral (BSBA) non-specific immunity in the animals was due to the synergistic effect of the toxin and the causative agent.

The increase in the BSCA activity was possibly related to the fact that the complement system is a complex multicomponent biological structure capable of self-regulation in cases of chemical or biological impacts. T-2 toxin is shown to inhibit the non-specific response by the reduction in the expression of TLRs (tolllike receptors) on the surface of the immune competent cells [36].

In our experiments with albino rats, we noted an increase in the titer of natural antibodies, a considerable reduction in PAL, PC, PI, as well as in the content of lysozyme, which represent the first line of defense of the body, and a marked suppression of the T-lymphocyte system, especially in the animals infected with a higher dose of Salmonella. The decrease in the T-cell count was accompanied by a lower IL-2 concentration in blood.

The infection of the rats with Salmonella against the background of intoxication promoted a better differentiation (percentage) of B-lymphocytes, an increase in the total immunoglobulin concentration in blood and the induction of anti-salmonella antibodies. The animals which received a higher dose of the toxin showed more marked polyclonal stimulation of the humoral immunity, although the production of specific antibodies declined, which was also influenced by the acquired T-deficit.

Moreover, we noted a positive relation between the content of interleukins (IL-1 $\beta$, IL-2 and IL-4) and corresponding indicators of the immune status in the animals. C-reactive protein appeared in the blood of the experimental rats indicating the development of an inflammatory process.

Thus, under ecologically unfavorable conditions simulated by a toxicant and a potential pathogen, we can observe an imbalance in the functioning of the albino rats' defense systems, which is characterized by the suppression of the protein synthesis, T-group of the immune system, IL-2 biosynthesis, phagocytosis, by an increase in the catabolism of immunoglobulins, lysozyme content and, on the other hand, by an increase in the amount of complement system proteins (total hemolytic complement activity), IL-1 $\beta$, as well as by the activation of the humoral immunity, production of IL-4, leukocytosis, neutrophilia and biosynthesis of acute-phase proteins, in particular CRP (C-reactive protein).

\section{REFEREN C ES}

1. S mi rnov A.M. Materialy Mezhdunarodnogo koordinatsionnogo soveshchaniya «Ekologicheskie problemy patologii, farmakologii terapii» [Proc. Int. Meeting «Pathology, pharmacology and therapy: environmental aspects»]. Voronezh, 1997: 8-11. 
2. I d ris o v G.Z. Materialy Vserossiiskoi nauchnoi-prakticheskoi konferentsii «Agroekologicheskie problemy sel'skokhozyaistvennogo proizvodstva $v$ usloviyakh tekhnogennogo zagryazneniya agroekosistem» [Proc. All-Russian Conf. «Agriculture under technogenic pollution of agroecosystems». Part II]. Kazan', 2002, chast' II: 245-248.

3. Grudina N.V., Bastrakova L.A., Isakova V.N., Bastrakova L.A., Isakova V.I., S arukhanov V.Ya., Kozlov V.A., Zhuk ov I.V. Materialy Vserossiiskoi nauchnoi-prakticheskoi konferentsii «Agroekologicheskie problemy sel'skokhozyaistvennogo proizvodstva $V$ usloviyakh tekhnogennogo zagryazneniya agroekosistem» [Proc. All-Russian Conf. «Agriculture under technogenic pollution of agroecosystems». Part II]. Kazan', 2002, chast' II: 248-252.

4. Do n n ik I.M., I s a e va A.G. Materialy Vserossiiskoi nauchnoi-prakticheskoi konferentsii «Agroekologicheskie problemy sel'skokhozyaistvennogo proizvodstva $v$ usloviyakh tekhnogennogo zagryazneniya agroekosistem» [Proc. All-Russian Conf. «Agriculture under technogenic pollution of agroecosystems». Part II]. Kazan', 2002, chast' II: 253-255.

5. Donnik I.M., Mymrin V.S., Loretts O.G., Likhodeevskaya O.E., Bar a s h k i n M.I. Agrarnyi vestnik Urala, 2013, 5(111): 15-19.

6. Oswald I.P., Marin D.E., B ouhet S., Pinton P., Taranu I., Accensi F. Immunotoxicological risk of mycotoxins for domestic animals. Food Additives \& Contaminants, 2005, 22(4): 354-360 (doi: 10.1080/02652030500058320).

7. Vand e n b ro c k e V. Double trouble: interactions between deoxynivalenol and the pathogenesis of Salmonella typhimurium infections in pigs. Zelzate, 2011.

8. Vandenbroucke V., Croubels S., Martel A., Verbrugghe E., Goos sens J., Van Deun K., B oyen F., Thompson A., Shearer N., De Backer P., $\mathrm{H}$ a es ebrouck F., P as mans F. The mycotoxin deoxynivalenol potentiates intestinal inflammation by Salmonella typhimurium in porcine ileal loops. PLOS ONE, 2011, 6(8): 1-8 (doi: 10.1371/journal.pone.0023871).

9. Waldemarson A.H., Hed enquist P., Salomonsson A.-C., Haggblom P. Mycotoxins in laboratory rodent feed. Laboratory Animals, 2005, 39: 230-235 (doi: $10.1258 / 0023677053739819)$.

10. Fung F., Clark R.F. Health effects of mycotoxins: a toxicological overview. J. Toxicol. Clin. Toxicol., 2004, 42(2): 217-234 (doi: 10.1081/clt-120030947).

11. S chothorst R.C., van Eg mond H.P. Report from SCOOP task 3.2.10 «collection of occurrence data of Fusarium toxins in food and assessment of dietary intake by the population of EU member states»: Subtask: trichothecenes. Toxicol. Lett., 2004, 153: 133-143 (doi: 10.1016/j.toxlet.2004.04.045).

12. Li M., Harkema J.R., Is 1 a m Z., Cuff C.F., Pestk a J.J. T-2 toxin impairs murine immune response to respiratory reovirus and exacerbates viral bronchiolitis. Toxicol. Appl. Pharmacol., 2006, 217: 76-85 (doi: 10.1016/j.taap.2006.08.007).

13. Kamalavenkatesh P., Vairamuthu S., Balachandran C., Murali Ma$\mathrm{noh}$ a $\mathrm{r}$ B., D hi n a k r R a j G. Immunopathological effect of the mycotoxins cyclopiazonic acid and T-2 toxin on broiler chicken. Mycopathologia, 2005, 159: 273-279.

14. Meissonnier G.M., Laffite J., Raymond I., Benoit E., Cossalter A.-M., P int on P., B e rt in G., O swald I.P., G a lt i e r P. Subclinical doses of T-2 toxin impair acquired immune response and liver cytochrome P450 in pigs. Toxicology, 2008, 247: 4654 (doi: 10.1016/j.tox.2008.02.003).

15. S hak hov A.G., A rgu nov M.N., B u z l a m a V.S. Veterinariya, 2003, 5: 3-6.

16. Shakhov A.G., A rgu nov M.N., B u z l a m a V.S. Zootekhniya, 2003, 2: 21-24.

17. Tersago K., De Coen W., Scheirs J., Vermeulen K., Blust R., Van B ockstaele D., Verhagen R. Immunotoxicology in wood mice along a heavy metal pollution gradient. Environ. Pollut., 2004, 132(3): 385-394 (doi: 10.1016/j.envpol.2004.05.029).

18. Mc Manus J., Huebner K. M. Vesicants. Crit. Care Clin., 2005, 21(4): 707-718 (doi: 10.1016/j.ccc.2005.06.005).

19. Ge rlach R., He nsel M. Salmonella pathogenicity islands in host specificity, host pathogen-interactions and antibiotics resistance of Salmonella enterica. Berl. Munch. Tierarztl. Wochenschr, 2007, 120(7-8): 317-327.

20. Cha in ik ova I.N. Vestnik OGU (Orenburg), 2005, 12: 58-62.

21. Law le y T., B oul e y D., H o y Y. Host transmission of Salmonella enterica serovar Typhimurium is controlled by virulence factors and indigenous intestinal microbiota. Infect. Immun., 2008, 76(1): 403-416 (doi: 10.1128/IAI.01189-07).

22. Coburn B., Grass 1 G., Finlay B. Sallmonella, the host and disease: a brief review. Immunol. Cell. Biol., 2007, 85(12): 112-118 (doi: 10.1038/sj.icb.7100007).

23. GOST R53434-2009. Printsipy nadlezhashchei laboratornoi praktiki [RF State Standard R53434-2009. Principles of reliable laboratory practice]. Moscow, 2009.

24. Shakhov A.G., Brigadirov Yu.N., Anufriev A.I., Biryukov M.V., Pershina S.I., Kardashov A.M., Petrova M.G., Batishcheva E.V., Buzla- 
ma V.S., B e 1 y a e v V.I., M a ty ushevski i L.A., F e dorov Yu.N., A rgunov M.N., Panin A.N., Kalyuzhnyi I.I., Donnik I.M., Tatarchuk A.T., Gorlov I.F., Balakirev N.A., Maiorov A.I., E mel'yanenko P.A., Kiril lov A.K., Maiorov M.A., Goryachev A.A., Evdokimov V.V., Voronin E.S., M a maev N.Kh., D zha malud inova I.N., S is yag in P.N., I saev V.V., Redzhepova G.R., Gorbunov A.P., Boyarintsev L.E., Klimenko V.V, Topuriy a G.M., Topuriy a L.Yu., Zhuk ov A.P. V sbornike: Novye metody issledovanii po problemam veterinarnoi meditsiny [In: Survey in veterinary medicine: recent methods. Part III]. Moscow, 2007, chast' III: 174-215.

25. Shakhov A.G., Mas'yanov Yu.N., Retskii M.I., Brigadirov Yu.N., Anufriev A.I., Biryukov M.V., Pershina S.I., Kardashov A.M., Petrova M.G., B at ishcheva E.V., B elyaev V.I., Zolotarev A.I., Bliznetsova G.N., Buzlama V.S., Sule imanov S.M., Fedorov Yu.N., Borzenko E.V., Khanis A.Yu., Borzenko T.V., Artemov B.T., Efanova L.I., Manzhurina O.A., Panin A.N., Makarov Yu.A., Donnik I.M., Tatarchuk A.T., Gorlov I.F., Balakirev N.A., Maiorov A.I., Emel'yanenko P.A., Kirillov A.K., Maiorov M.A., Goryachev A.A., Evdokimov V.V., Voronin E.S., Sisyagin P.N., I s a ev V.V., Redzhepova G.R., Kaverin N.N., Arte m'eva S.S., Topuriya G.M., Topuriya L.Yu., Zhukov A.P., Kalyuzhnyi I.I., Mamae v N.Kh., D z ha ma lu d i nova I.N. V sbornike: Novye metody issledovanii po problemam veterinarnoi meditsiny [In: Survey in veterinary medicine: recent methods. Part III]. Moscow, 2007, chast' III: 216-291.

26. Weaver D.M., Tyle r J.W., Van Metre D.C., Hostetler D.E., Barringt o n G.M. Passive transfer of colostral immunoglobulins in calves. J. Vet. Int. Med., 2000, 14 : 469-577 (doi: 10.1111/j.1939-1676.2000.tb02278.x).

27. Sidorov M.A., Sk orodu mov D.I. Fedotov V.B. Opredelitel' zoopatogennykh mikroorganizmov [Zoopathogenic microorganisms: key for identification]. Moscow, 1995.

28. Y u n k e rov V.I., Grig o r'ev S.G. Matematiko-statisticheskaya obrabotka dannykh meditsinskikh issledovanii [Statistical processing in medical survey]. St. Petersburg, 2002.

29. Pare nt-Massin D. Haematotoxicity of trichothecenes. Toxicol. Lett., 2004, 153: 75-81 (doi: 10.1016/j.toxlet.2004.04.024).

30. Hymery N., Léon K., Carpentie r F.-G., Jung J.-L., Parent-Massin D. T-2 toxin inhibits the differentiation of human monocytes into dendritic cells and macrophages. Toxicology in Vitro, 2009, 23: 509-519 (doi: 10.1016/j.tiv.2009.01.003).

31. Minervini F., Fornelli F., Lucivero G., Romano C., Visconti A. T-2 toxin immunotoxicity on human B and T lymphoid cell lines. Toxicology, 2005, 210: 81-91 (doi: 10.1016/j.tox.2005.01.007).

32. Roch a O., A ns ari K., D o oh a n F.M. Effects of trichothecene mycotoxins on eukaryotic cells: a review. Food Addit. Contam., 2005, 22: 369-378 (doi: 10.1080/02652030500058403).

33. Ravindrana J., Agrawal M., Guptab N., Lakshmana Rao P.V. Alteration of blood brain barrier permeability by T-2 toxin: Role of MMP-9 and inflammatory cytokines. Toxicology, 2010, 280: 44-52 (doi: 10.1016/j.tox.2010.11.006).

34. D y ck R.F., Iss a M.I.C., Rogers S.L., Murphy F., Khachatourians G.G. The effect of T-2 toxin on the acute phase reaction in mice. Journal of American College of Toxicology, 1985, 4(1): 71-78 (doi: 10.3109/10915818509014506).

35. Shakhov A.G., S a shnina L.Yu., M as 'yanov Yu.N., Vostroilova G.A., E ri n a T.A. V sbornike nauchnykh trudov FGBOU VPO NGSKHA, predstavlennykh na 2-i sessii Mezhdunarodnoi nauchno-prakticheskoi konferentsii «Populyatsionnoe zdorov'e zhivotnykh $i$ emerdzhentnye infektsii v sovremennykh usloviyakh» [In: Proceedings of N. Novgorod Agricultural Academy submitted to Int. Conf. «Farm animal health and emergent infections in populations». Part 1. V.V. Sochnev (ed.)]. N. Novgorod, 2015, chast' 1: 499-506.

36. Se eboth J., Solinhac R., Oswald I.P., Guzylack-Piriou L. The fungal T-2 toxin alters the activation of primary macrophages induced by TLR-agonists resulting in a decrease of the inflammatory response in the pig. Veterinary Research, 2012, 43(35): 1-11 (doi: 10.1186/1297-9716-43-35). 